Tropical Journal of Pharmaceutical Research January 2021; 20 (1): 145-153

ISSN: $1596-5996$ (print); 1596-9827 (electronic) (C) Pharmacotherapy Group, Faculty of Pharmacy, University of Benin, Benin City, 300001 Nigeria.

\title{
Synthesis and characterization of some new Schiff base derivatives of gabapentin, and assessment of their antibacterial, antioxidant and anticonvulsant activities
}

\author{
Muhammad Farrukh Saleem ${ }^{1}$, Mohsin Abbas Khan ${ }^{1}$, Irshad Ahmad ${ }^{1 *}$, Naveed \\ Aslam $^{2}$, Umair Khurshid ${ }^{1}$ \\ ${ }^{1}$ Department of Pharmaceutical Chemistry, Faculty of Pharmacy and Alternative Medicine, The Islamia University of \\ Bahawalpur, Bahawalpur, ${ }^{2}$ Primary and Secondary Healthcare Department, Government of Punjab, Pakistan
}

*For correspondence: Email: irshad.ahmad@ub.edu.pk; Tel: +92-3006829701

Sent for review: 20 July 2020

Revised accepted: 20 December 2020

\begin{abstract}
Purpose: To synthesize and characterize some new gabapentin Schiff base derivatives, and to assess their antibacterial, antioxidant and antiepileptic activities.

Methods: Four Schiff base derivatives of gabapentin, termed G1, G2, G3 and G4, were synthesized by condensation with benzoin, vanillin, acetophenone, and benzophenone, respectively. Their chemical identities were established by FTIR, ${ }^{1} \mathrm{H}$ NMR and ${ }^{13} \mathrm{C} N M R$ techniques. The new compounds were screened for antibacterial activity using agar well method, antioxidant activity by DPPH assay, and anticonvulsant activity against pentylenetetrazole (PTZ) induced seizures in mice.

Results: All the compounds showed antibacterial activity against the test strains to variable degrees, while the parent drug did not exhibit antibacterial activity. The zones of inhibition of compound G2 against Micrococcus luteus $(36.2 \pm 1.0 \mathrm{~mm})$ and Serratia marcescens $(28.2 \pm 1.0 \mathrm{~mm})$, and of compound G4 against Stenotrophomonas maltophilia $(36.8 \pm 1.0 \mathrm{~mm})$ were larger compared to the standard drug, doxycycline, exhibiting zones of inhibition $28.2 \pm 1.3,28.2 \pm 0.9$ and $20.0 \pm 0.9 \mathrm{~mm}$, respectively. In addition, compounds $G 1$ and $G 2$ possessed significantly greater $(p<0.05)$ radical scavenging activity $(82.3 \pm 1.8$ and $92.3 \pm 2.2 \%$, respectively) than the precursor drug, gabapentin $(63.2 \pm 2.6 \%)$. The seizure scores for compounds $\mathrm{G} 1(0.7 \pm 0.06)$ and $\mathrm{G} 2(0.9 \pm 0.07)$ were comparable $(p>0.05)$ with gabapentin $(0.8 \pm 0.06)$, while compounds $G 3$ and $G 4$ were less active $(p<0.05)$ than gabapentin.

Conclusion: Compounds $\mathrm{G} 1$ and $\mathrm{G} 2$ exhibit good antibacterial and antioxidant activities while retaining the anticonvulsant activity of the parent drug, gabapentin, thus making them suitable candidates for further development for the treatment of neurodegenerative pathologies associated with bacterial infections.
\end{abstract}

Keywords: Gabapentin, Antibacterial, Seizures, Antioxidant, Anticonvulsant

This is an Open Access article that uses a fund-ing model which does not charge readers or their institutions for access and distributed under the terms of the Creative Commons Attribution License (http://creativecommons.org/licenses/by/4.0) and the Budapest Open Access Initiative (http://www.budapestopenaccessinitiative.org/read), which permit unrestricted use, distribution, and reproduction in any medium, provided the original work is properly credited.

Tropical Journal of Pharmaceutical Research is indexed by Science Citation Index (SciSearch), Scopus, International Pharmaceutical Abstract, Chemical Abstracts, Embase, Index Copernicus, EBSCO, African Index Medicus, JournalSeek, Journal Citation Reports/Science Edition, Directory of Open Access Journals (DOAJ), African Journal Online, Bioline International, Open-J-Gate and Pharmacy Abstracts

\section{INTRODUCTION}

Schiff bases, named after chemist Hugo Schiff, are formed when any primary amine reacts with a ketone or aldehyde under controlled conditions. A Schiff base is the nitrogen analogue of a ketone or aldehyde in which the carbonyl functional group $(\mathrm{C}=\mathrm{O})$ is substituted by an 
azomethine (-N=C-) group [1,2]. Schiff base molecules derived from aromatic ketones, aldehydes and their derivatives are quite stable [3].

Schiff bases have been reported to play many important roles in the medicinal field. They have been reported to possess diversified biological activities including anticonvulsant [4], gastroprotective [5], anti-tuberculosis, anticancer, analgesic, anti-inflammatory, antiplasmodial, antibacterial, antifungal and antioxidant [2] activities. The nitrogen atom in azomethine group of Schiff base derivative carries lone pair of electrons in $s p^{2}$ hybridized orbital, which can easily interact with several cellular macromolecules by forming hydrogen bond resulting change in cellular functions and possible altered therapeutic activity of the parent molecule [6].

Schiff bases have well-established broadspectrum antimicrobial and cytotoxic activities $[2,7]$. Schiff base compounds derived from neuromodulating drugs, such as clobazam [8], lamotrigine [9] and carbamazepine [10] moieties exhibited pronounced antibacterial activities. Gabapentin or 2-(1-(aminomethyl)cyclohexyl) acetic acid, is structurally similar to $y$ aminobutyric acid (GABA), and is recommended for treatment of seizures, chronic pain syndromes and diabetic neuropathy [11]. A Schiff base derivative of gabapentin and copper complex have shown good anticancer activity [12].

Some Schiff base derivatives of gabapentin were assessed for their antioxidant and anticonvulsant potential [4]. In recent years, research on the role of reactive oxygen species in the pathogenesis of various human diseases has indicated that antioxidants may be beneficial in the treatment and prevention of several diseases, including neurodegenerative, cardiovascular, autoimmune and infectious diseases. Oxidative stress is an important etiological factor in epileptic seizures and antioxidants may provide neuroprotection to prevent seizures [13]. Antioxidants may also provide protection against pathological consequences of several infectious diseases [14]. Therefore, antioxidant compounds are gaining increased attention in medical research.

The literature survey revealed that apart from the compound G2 [4], synthesis and antioxidant activities of the compounds G1, G3 and G4 have never been reported. In addition, there are presently no studies reporting the antibacterial and anticonvulsant activities of the synthesized compounds. Keeping the above facts in mind and with an interest in developing new lead compounds possessing antibacterial, antioxidant and antiepileptic activities, we synthesized four Schiff's base compounds from gabapentin (G1G4). The new synthesized compounds were chemically characterized and their antibacterial, antioxidant and anticonvulsant effects were studied using in vivo and in vitro models.

\section{EXPERIMENTAL}

\section{Chemical and reagents}

All the chemicals and reagents used in the present study were of analytical grade. Ethanol, vanillin, acetophenone and acetic acid were purchased from Sigma Chemicals USA. 2,2diphenyl-1-picrylhydrazyl (DPPH), benzophenone, benzoin, ascorbic acid, diazepam and pentylenetetrazole (PTZ) were obtained from Merck. Gabapentin (96\%, USP grade) was obtained from Highnoon laboratories Pvt. Ltd Lahore.

\section{Animals}

Swiss mice (20 - $25 \mathrm{~g}$; either sex) were used for the evaluation of anticonvulsant activity. The mice were housed in polycarbonate cages at room temperature $\left(23-27^{\circ} \mathrm{C}\right)$ under $12 \mathrm{~h}$ light$12 \mathrm{~h}$ dark cycles at animal house facility of the Department of Pharmacy, the Islamia University Bahawalpur. The guidelines for care and use of laboratory animals issued by National Research Council [15] were complied with and their use was allowed by the institutional ethical committee.

\section{Preparation of Schiff base derivatives}

Ethanol solution of gabapentin $(1.0 \mathrm{~g}$ in $60 \mathrm{~mL})$ was mixed with equimolar quantity of the available aldehyde or ketones in a $250 \mathrm{~mL}$ round bottom flask. Glacial acetic acid $(2 \mathrm{~mL})$ was used as catalyst. The mixture was refluxed for $4-5 \mathrm{~h}$. The product was obtained by pouring the reaction mixture into ice cold water. After filtration it was crystallized from ethanol [16]. The general chemical reaction is described in Figure 1. The four new Schiff base compounds of gabapentin were synthesized by condensation with benzoin, vanillin, acetophenone and benzophenone with respective names of $\mathrm{G} 1, \mathrm{G} 2, \mathrm{G} 3$ and $\mathrm{G} 4$; their formulas as confirmed in the present study are given in Figure 2.

\section{Chemical characterization}

Identification of chemical structures and purity of the synthesized compounds was achieved by 
already reported methods [12,17]. The solubility of the derived compounds was determined in various solvents, including water, chloroform, DMSO and ethanol by using ultra-sonicator (Model 30H, Elma Schmidbauer $\mathrm{GmbH}$, Germany). Melting points of the derived compounds were determined by adding a small quantity of synthesized compound in a capillary tube and heating the capillary tube in melting point apparatus (Galen Kemp). Infrared spectrum (4000-400 $\mathrm{cm}^{-1}$ ) of the synthesized compounds was obtained in $\mathrm{KBr}$ pellets by means of FTIR spectrophotometer (Bruker Tensor-27 FTIR spectrometer). ${ }^{1} \mathrm{H}$ NMR and ${ }^{13} \mathrm{C}$ NMR spectra of derived compounds were obtained by Bruker 400 spectrophotometer.

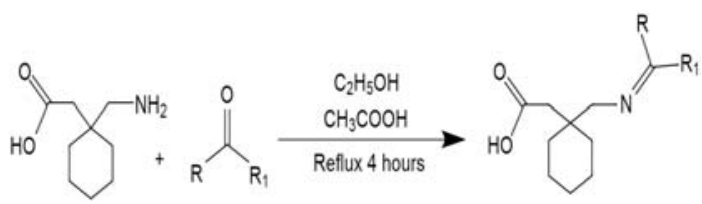

Figure 1: Chemical reaction showing synthesis of gabapentin Schiff base compound

\section{Antimicrobial screening}

Antibacterial activity of gabapentin and its derived Schiff base compounds was determined by agar well diffusion method [18] against four strains of Gram positive bacteria (Bacillus megaterium, Bacillus subtilis, Micrococcus luteus and Staphylococcus aureus) and three strains of gram negative bacteria (Stenotrophomonas maltophilia, Serratia marcescens, and Escherichia coli). The Mueller Hinton agar medium in pert plates was sterilized in autoclave and allowed to cool it at about $45^{\circ} \mathrm{C}, 100 \mu \mathrm{L}$ standard inoculum was aseptically mixed, cooled to $37^{\circ} \mathrm{C}$, and $6 \mathrm{~mm}$ well were made in the agar plate. The derived compound or the standard drug was dissolved in DMSO to make 0.125 , 0.25 and $0.5 \mathrm{mg} / \mathrm{mL}$ solution, from which $30 \mu \mathrm{L}$ of the sample solution was poured in the agar medium wells. The prepared petri dishes were kept at $37^{\circ} \mathrm{C}$ in incubator for $24 \mathrm{~h}$ and zones of inhibition measured in $\mathrm{mm}$. The tests were performed in triplicate. The solvent used did not inhibit bacterial growth (data not shown). Doxycycline was used as a standard drug.

\section{Antioxidant assay}

Antioxidant activity of the derivatives was determined by using 2,2-dipheynyl-1picrylhydrazyl radical (DPPH) assay [19]. The DPPH solution $(2.0 \mathrm{ml} ; 0.2 \mathrm{mg} / \mathrm{mL}$ in methanol) and test material solution $(1.0 \mathrm{~mL} ; 0.2 \mathrm{mg} / \mathrm{mL}$ in methanol) were mixed in a reaction tube and allowed to stand for $30 \mathrm{~min}$ at room temperature to complete reaction. When $\mathrm{DPPH}$ radical is scavenged, its color is changed from purple to yellow, resulting in a decrease in absorbance at $517 \mathrm{~nm}$. Absorbance of the reaction mixture at $517 \mathrm{~nm}$ was taken by using a UV-Visible spectrophotometer. Absorbance of blank sample containing $1.0 \mathrm{ml}$ of methanol and $2.0 \mathrm{~mL}$ of DPPH solution was also measured. Inhibition was calculated in terms of scavenging activity (S) as in Eq 1.

$S(\%)=\left\{\left(A_{b}-A_{t} / A_{b}\right)\right\} 100 \ldots \ldots .(1)$

where $A_{t}$ and $A_{b}$ are absorbance of test and blank samples, respectively.

\section{Anticonvulsant activity}

Anticonvulsant effects of synthesized compounds were observed in vivo by acute intraperitoneal PTZ test. The synthesized compounds were injected into the mice $(n=6)$ at the doses of 10 , 35 and $75 \mathrm{mg} / \mathrm{kg}$, respectively. Thirty min later, mice were injected with $90 \mathrm{mg} / \mathrm{kg}$ of $\mathrm{PTZ}$ (convulsive dose) and were observed for $60 \mathrm{~min}$ for the assessment of PTZ-induced mortality [20].

Once screening in the acute seizure model was done, the next step was the assessment of the effects of the synthesized compounds on PTZ kindling model of epileptogenesis in albino mice [20]. The mice were randomized into four groups $(\mathrm{n}=8)$ and based on results obtained from acute testing, $75 \mathrm{mg} / \mathrm{kg}$ doses of the synthesized compounds were selected. All groups except the normal control group received $50 \mathrm{mg} / \mathrm{kg}$ subconvulsive dose of PTZ through intraperitoneal route once on alternate day. The normal control group and the drug control group were given daily dose of $0.25 \mathrm{~mL}$ of normal saline and 7.5 $\mathrm{mg} / \mathrm{kg}$ diazepam, respectively. Similarly, the synthesized compounds were administered once daily to the test groups. The study was carried out for 24 days for the development of epileptogenesis in the PTZ kindling model while a gradual increase and rise in the seizure pattern was observed. After the last treatment dose of PTZ, convulsive score was calculated in each group by using the following criteria: No seizure $=0$, initiation of body jerks $=1$, manifestation of seizures $=2$, generalized seizures with loss of righting reflex $=3$, tonic forelimb with loss of righting reflex $=4$, and hind limb extension $=5$.

\section{Statistical analysis}

The results of biological activities are shown as mean or mean \pm SEM. Comparison between different groups was made by applying one-way 
ANOVA, while $p$ value $<0.05$ was taken as level of significance.

\section{RESULTS}

\section{Chemical characteristics}

The results of chemical characterization of compounds G1, G2, G3 and G4 are given below and their structures are shown in Figure 2.
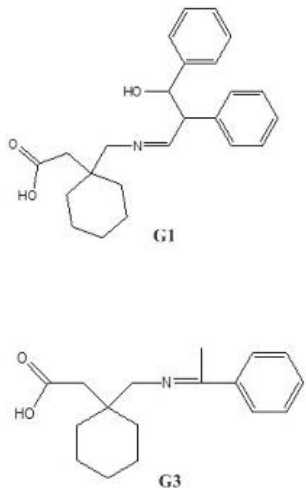

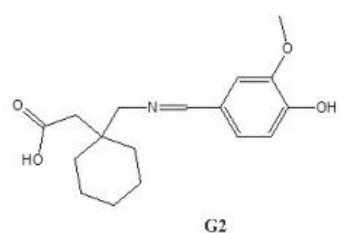

G2



G4
Figure 2: Chemical structures of the synthesized compounds

\section{Spectral characteristics}

G1: diphenylpropylideneamino) cyclohexyl) acetic acid

2-(1-((3-hydroxy-2,3methyl)

Yield 76\%; Insoluble in water, but soluble in DMSO, ethanol and chloroform; melting point $172^{\circ} \mathrm{C}-176^{\circ} \mathrm{C}$; molecular weight 379.50 ; molecular formula $\mathrm{C}_{24} \mathrm{H}_{29} \mathrm{NO}_{3}$; elemental analysis (calculated) $\mathrm{C}=75.96, \mathrm{H}=7.70, \mathrm{~N}=3.69, \mathrm{O}=$ 12.65. FT-IR v cm${ }^{-1}$ : $3841(\mathrm{COOH}), 2926(\mathrm{CH})$, $1682(\mathrm{C}=\mathrm{O}), 1452(\mathrm{CH}=\mathrm{CH}), 1657(\mathrm{C}=\mathrm{N}), 1253$ $(\mathrm{C}-\mathrm{O})$ and $3649(\mathrm{OH})$

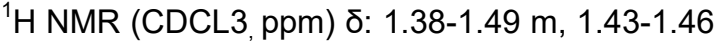
m, 1.24-1.49 t $\left(-\mathrm{CH}_{2}-\right)$, 7.1-7.2 t, 7.0-7.08 t, 7.07.19 d, 7.4-7.5 d, 2.0-2.15 s (-CH-), $10.15 \mathrm{~s}$ $(-\mathrm{OH})$.

${ }^{13} \mathrm{C}$ NMR (CDCL3, ppm) ס: 22.9 (C-1), 22.9 (C3/5), 226.0 (C-4), 55.8 (C-7), 51.6 (C-8), 162.9 (C-9), 161 (C-10), 36.84 (C-11), 140 (C-12), 123 (C-13/17), 123 (C-14/15), 123 (C-15/16), 77.2 (C18), 128 (C-19/20), 128 (C-21/22), 128 (C-23).

G2: 2-(1-((4-hydroxy-3-methoxybenzylideneamino) methyl) cyclohexyl) acetic acid

Yield 75\%; Insoluble in water, but soluble in DMSO, ethanol and chloroform; melting point $166^{\circ} \mathrm{C}-169^{\circ} \mathrm{C}$; molecular weight 305.37 ; molecular formula $\mathrm{C}_{17} \mathrm{H}_{23} \mathrm{NO}_{4}$; elemental analysis (calculated): $\mathrm{C}=66.86, \mathrm{H}=7.59, \mathrm{~N}=4.59, \mathrm{O}=$ 20.96.

FT-IR v cm${ }^{-1}: 3841(\mathrm{COOH}), 2869(\mathrm{CH}), 1682$ $(\mathrm{C}=\mathrm{O}), 1452(\mathrm{CH}=\mathrm{CH}), 1682(\mathrm{C}=\mathrm{N}), 1253(\mathrm{C}-\mathrm{O})$, ${ }^{1} \mathrm{H}$ NMR (CDCL3, ppm) $\delta: 1.40-1.41 \mathrm{~m}, 1.42-1.43$ $\mathrm{t}, 3.11-3.12 \mathrm{~s}\left(-\mathrm{CH}_{2}-\right), 6.91-7.0 \mathrm{~d}, 6.8-6.9 \mathrm{~s}$ $(-\mathrm{CH}-), 9.74 \mathrm{~s}(-\mathrm{OH}), 9.74 \mathrm{~s}\left(-\mathrm{NH}_{2}\right), 3.76 \mathrm{~s}(-$ CH3-)

${ }^{13} \mathrm{C}$ NMR (CDCL3, ppm) ס: 22.5 (C-1), 36.49 (C2), 22.5 (C-3), 25.0 (C-4), 36.37(C-6), 55.8 (C-7), 43 (C-8), 177 (C-9), 160 (C-10), 133 (C-11), 114 (C-12), 151 (C-13), 148 (C-14), 117 (C-15), 122 (C-16), 55 (C-17).

\section{G3: 2-(1-((1-phenylethylideneamino) methyl) cyclohexyl) acetic acid}

Yield $78 \%$. Insoluble in water, but soluble in DMSO, ethanol and chloroform; melting point $164^{\circ} \mathrm{C}-168^{\circ} \mathrm{C}$; molecular weight 273.38 , molecular formula $\mathrm{C}_{17} \mathrm{H}_{23} \mathrm{NO}_{2}$; elemental analysis (calculated): $\mathrm{C}=74.69, \mathrm{H}=8.48, \mathrm{~N}=5.12, \mathrm{O}=$ 11.70 .

FT-IR v cm ${ }^{-1}: 3841(\mathrm{COOH}), 2869(\mathrm{CH}), 1682$ $(\mathrm{C}=\mathrm{O}), 1452(\mathrm{CH}=\mathrm{CH}), 1682(\mathrm{C}=\mathrm{N}), 1253(\mathrm{C}-\mathrm{O})$, ${ }^{H} \mathrm{H}$ NMR (CDCL3, ppm) $\delta: 1.41-1.42 \mathrm{~m}, 1.40-$ $1.41 \mathrm{~m}, 1.2-1.4 \mathrm{t}, 2.1-2.5 \mathrm{~s}, 3.0-3.1 \mathrm{~s}\left(-\mathrm{CH}_{2}-\right)$, 7.2-7.3 t, 7.5-7.9 d (-CH-), $8.37 \mathrm{~s}(-\mathrm{OH})$.

${ }^{13} \mathrm{C}$ NMR (CDCL3, ppm) ס: 22.8 (C-1/3), 36.7 (C2), 26.0 (C-4), 22.8 (C-5), 36.7 (C-6), 53 (C-7), 43.2 (C-8), 177 (C-9), 178 (C-10), 137 (C-11), 128 (C-12), 126 (C-13), 133 (C-14), 128 (C-15), 128 (C-16), 21 (C-17).

\section{G4: 2-(1-((diphenylmethyleneamino) methyl) cyclohexyl) acetic acid}

Yield 73\%; Insoluble in water, but soluble in DMSO, ethanol and chloroform; melting point $174^{\circ} \mathrm{C}-176^{\circ} \mathrm{C}$; molecular weight 335.50 ; molecular formula $\mathrm{C}_{22} \mathrm{H}_{25} \mathrm{NO}_{2}$; elemental analysis (calculated): $\mathrm{C}=78.77, \mathrm{H}=7.51, \mathrm{~N}=4.18, \mathrm{O}=$ 9.54. FT-IR v cm${ }^{-1}: 3841(\mathrm{COOH}), 2869(\mathrm{CH})$, $1682(\mathrm{C}=\mathrm{O}), 1452(\mathrm{CH}=\mathrm{CH}), 1682(\mathrm{C}=\mathrm{N}), 1253$ $(\mathrm{C}-\mathrm{O})^{1} \mathrm{H}$ NMR (CDCL3, ppm) $\delta: 1.42-1.44 \mathrm{~m}$, 1.44-1.48 t $\left(-\mathrm{CH}_{2}-\right), 7.46-7.48 \mathrm{~m}, 7.24-7.2 \mathrm{t}$, 7.70.0-7.76 d, 7.6-7.7 d (-CH-), 17.80-7.81s $(-\mathrm{OH})$.

${ }^{13} \mathrm{C}$ NMR (CDCL3, ppm) ס: 22.8 (C-1/5), 36.8 (C2), 22.8 (C-3), 25.6 (C-4), 36.8 (C-6), 53.6 (C-7), 43.19 (C-8), 178.19 (C-9/10), 137.56 (C-11), 128.28 (C-12/13), 130.4 (C-14), 128.8 (C-15/16), 137.56 (C-17), 128.28 (C-18/19), 132.5 (C-20), $128(\mathrm{C}-21 / 22)$. 


\section{Antibacterial activity}

Antibacterial activity of gabapentin, its Schiff base derivatives and doxycycline were studied using the agar well method at three doses -3.75 , 7.5 and $15.0 \mu \mathrm{g} /$ well and zones of bacterial growth inhibition were measured in $\mathrm{mm}$. The parent drug, gabapentin (G0), gave negative results as it did not inhibit any of the tested organism. Results of antibacterial activity of the tested compounds against gram positive bacterial strains are summarized in Table 1. Effects of the tested compounds against growth of Gram negative bacterial strains are presented in Table 2. All the Schiff base derivatives and the standard drug inhibited bacterial growth to variable extent.

Table 1: Antibacterial activity of gabapentin (G0), its Schiff base derivatives (G1, G2, G3 and G4) and doxycycline against gram positive bacterial strains

\begin{tabular}{|c|c|c|c|c|c|}
\hline \multirow[b]{2}{*}{ Compound } & \multirow[b]{2}{*}{$\begin{array}{l}\text { Dose } \\
\mu g / w e l l\end{array}$} & \multicolumn{4}{|c|}{ Zones of inhibition (mm) } \\
\hline & & $\begin{array}{c}\text { Bacillus } \\
\text { megaterium }\end{array}$ & $\begin{array}{l}\text { Bacillus } \\
\text { subtilis }\end{array}$ & $\begin{array}{c}\text { Micrococcus } \\
\text { luteus }\end{array}$ & $\begin{array}{c}\text { Staphylococcus } \\
\text { aureus }\end{array}$ \\
\hline \multirow[t]{3}{*}{ G0 } & 3.75 & - & - & - & - \\
\hline & 7.50 & - & - & - & - \\
\hline & 15.0 & - & - & - & - \\
\hline \multirow[t]{3}{*}{ G1 } & 3.75 & $11.3 \pm 0.9$ & $18.2 \pm 0.7$ & $14.0 \pm 1.2$ & $18.0 \pm 1.2$ \\
\hline & 7.50 & $14.0 \pm 1.2$ & $27.0 \pm 0.9$ & $27.0 \pm 0.9$ & $27.2 \pm 1.3$ \\
\hline & 15.0 & $25.0 \pm 0.9$ & $33.0 \pm 1.2$ & $35.4 \pm 1.5$ & $31.8 \pm 0.8$ \\
\hline \multirow[t]{3}{*}{ G2 } & 3.75 & $12.3 \pm 0.9$ & $20.0 \pm 0.3$ & $16.2 \pm 1.3$ & $14.0 \pm 0.6$ \\
\hline & 7.50 & $14.2 \pm 0.5$ & $32.2 \pm 1.0$ & $29.0 \pm 0.9$ & $24.3 \pm 1.5$ \\
\hline & 15.0 & $27.0 \pm 0.9$ & $37.0 \pm 0.3$ & $36.2 \pm 1.0$ & $34.0 \pm 0.3$ \\
\hline \multirow[t]{3}{*}{ G3 } & 3.75 & $12.0 \pm 0.6$ & $18.2 \pm 0.7$ & - & $12.0 \pm 1.2$ \\
\hline & 7.50 & $15.2 \pm 1.3$ & $20.0 \pm 1.2$ & $11.0 \pm 1.2$ & $16.2 \pm 0.7$ \\
\hline & 15.0 & $19.0 \pm 0.6$ & $28.2 \pm 0.7$ & $20.2 \pm 0.7$ & $24.8 \pm 0.7$ \\
\hline \multirow[t]{3}{*}{ G4 } & 3.75 & $12.2 \pm 0.7$ & $16.0 \pm 0.6$ & $15.2 \pm 1.3$ & $12.0 \pm 0.6$ \\
\hline & 7.50 & $18.0 \pm 0.9$ & $27.0 \pm 0.9$ & $21.0 \pm 0.3$ & $20.2 \pm 1.3$ \\
\hline & 15.0 & $22.2 \pm 0.7$ & $33.8 \pm 1.0$ & $26.2 \pm 0.7$ & $30.0 \pm 1.2$ \\
\hline \multirow[t]{3}{*}{ Doxycycline } & 3.75 & $10.0 \pm 0.6$ & $13.0 \pm 1.2$ & $12.2 \pm 0.7$ & $16.0 \pm 0.6$ \\
\hline & 7.50 & $15.0 \pm 1.2$ & $20.2 \pm 0.7$ & $18.2 \pm 0.7$ & $25.0 \pm 1.2$ \\
\hline & 15.0 & $24.8 \pm 1.0$ & $32.0 \pm 1.2$ & $28.2 \pm 1.3$ & $30.0 \pm 0.9$ \\
\hline
\end{tabular}

Values are mean \pm SEM of three observations. (-) indicates no activity, as no inhibition zone noted around the well

Table 2: Antibacterial activity of gabapentin (G0), its Schiff base derivatives (G1, G2, G3 and G4) and doxycycline against gram negative bacterial strains

\begin{tabular}{|c|c|c|c|c|}
\hline \multirow[b]{2}{*}{ Compound } & \multirow[b]{2}{*}{$\begin{array}{l}\text { Dose } \\
\mu g \text { /well }\end{array}$} & \multicolumn{3}{|c|}{ Zones of inhibition (mm) } \\
\hline & & $\begin{array}{c}\text { Stenotrophomonas } \\
\text { maltophilia }\end{array}$ & Serratia marcescens & $\begin{array}{c}\text { Escherichia } \\
\text { coli }\end{array}$ \\
\hline \multirow[t]{3}{*}{ G0 } & 3.75 & - & - & - \\
\hline & 7.50 & - & - & - \\
\hline & 15.0 & - & - & - \\
\hline \multirow[t]{3}{*}{ G1 } & 3.75 & $10.0 \pm 1.2$ & $9.0 \pm 1.5$ & $19.0 \pm 0.6$ \\
\hline & 7.50 & $16.2 \pm 0.8$ & $17.2 \pm 0.7$ & $29.2 \pm 0.4$ \\
\hline & 15.0 & $25.2 \pm 0.5$ & $25.5 \pm 1.0$ & $38.2 \pm 0.4$ \\
\hline \multirow[t]{3}{*}{ G2 } & 3.75 & $18.0 \pm 0.6$ & $10.0 \pm 0.6$ & $12.2 \pm 0.7$ \\
\hline & 7.50 & $21.2 \pm 0.7$ & $21.2 \pm 0.7$ & $23.2 \pm 0.7$ \\
\hline & 15.0 & $32.2 \pm 1.0$ & $28.2 \pm 1.0$ & $29.0 \pm 0.9$ \\
\hline \multirow[t]{3}{*}{ G3 } & 3.75 & $18.0 \pm 0.6$ & $7.0 \pm 0.6$ & $17.2 \pm 0.7$ \\
\hline & 7.50 & $34.0 \pm 0.6$ & $12.0 \pm 1.2$ & $24.2 \pm 0.4$ \\
\hline & 15.0 & $39.7 \pm 1.5$ & $21.2 \pm 0.7$ & $29.7 \pm 1.2$ \\
\hline \multirow[t]{3}{*}{ G4 } & 3.75 & $15.2 \pm 1.3$ & $10.0 \pm 0.6$ & $11.0 \pm 0.6$ \\
\hline & 7.50 & $29.0 \pm 0.6$ & $18.0 \pm 1.2$ & $21.2 \pm 0.7$ \\
\hline & 15.0 & $36.8 \pm 1.0$ & $24.2 \pm 0.7$ & $29.8 \pm 1.0$ \\
\hline \multirow[t]{3}{*}{ Doxycycline } & 3.75 & $16.2 \pm 0.7$ & $11.2 \pm 0.7$ & $15.0 \pm 0.6$ \\
\hline & 7.50 & $21.2 \pm 0.7$ & $15.2 \pm 0.7$ & $24.2 \pm 0.7$ \\
\hline & 15.0 & $28.0 \pm 0.9$ & $20.0 \pm 0.9$ & $35.2 \pm 1.0$ \\
\hline
\end{tabular}

Values are mean \pm SEM of three observations. (-) indicates no activity, as no inhibition zone noted around the well 


\section{Antioxidant assay}

The results of DPPH radical scavenging potential of gabapentin and its derivatives are shows Table 3. The compounds $\mathrm{G} 1$ and $\mathrm{G} 2$ caused greater scavenging, and G3 and G4 caused less scavenging of DPPH free radicals as compared to the parent drug (G0). Ascorbic acid was used as reference standard.

Table 3: The DPPH radical scavenging activity of gabapentin (G0), its derivatives (G1-G4) and ascorbic acid

\begin{tabular}{lc}
\hline $\begin{array}{l}\text { Compound } \\
(\mathbf{2 0 0} \mathbf{~} \mathbf{g} / \mathbf{m l})\end{array}$ & $\begin{array}{c}\text { DPPH radical } \\
\text { scavenging (\%) }\end{array}$ \\
\hline $\mathrm{G} 0$ & $63.2 \pm 2.6$ \\
$\mathrm{G} 1$ & $82.3 \pm 1.8^{*}$ \\
$\mathrm{G} 2$ & $92.3 \pm 2.2^{*}$ \\
$\mathrm{G} 3$ & $58.4 \pm 2.9$ \\
$\mathrm{G} 4$ & $32.4 \pm 1.6^{*}$ \\
Ascorbic acid & $96.0 \pm 1.2^{*}$ \\
\hline Values are mean \pm SEM of three observations. \\
*indicates significant ( $p<0.05)$ difference, as \\
compared to G0, as analyzed by one-way ANOVA
\end{tabular}

\section{Anticonvulsant activity}

Administration of PTZ to mice in saline treated control group caused convulsions with $100 \%$ morality in mice. All the test compounds showed dose related protection from convulsive deaths in mice, as shown in Table 4.

In 24 days PTZ-induced chemical kindling model, administration of PTZ at $50 \mathrm{mg} / \mathrm{kg}$ did not produce seizures on first day of the treatment in either the control or in the test groups. At the end of experiment, average convulsive score for the positive control group was found greater than 4 . Other test groups showed protection from PTZseizures to various extent as summarized in Table 5 and Figure 3.

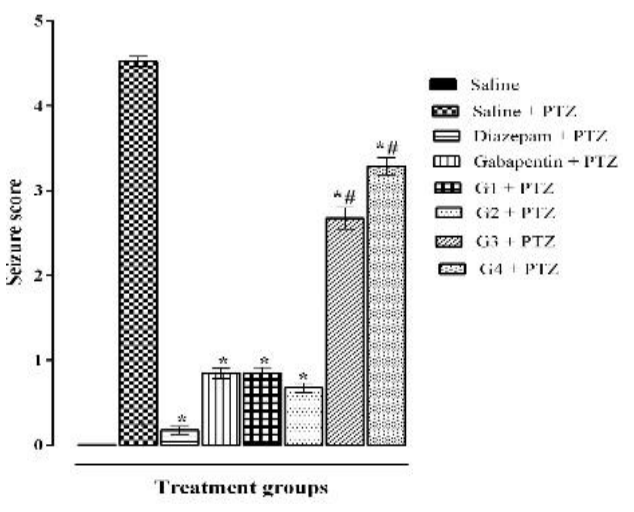

Figure 3: Anticonvulsant activity of different drugs and synthesized compounds in PTZ-evoked chemical kindling model of epileptogenesis in mice. Values are mean \pm SEM of eight observations. *indicates significant $(p<0.05)$ difference from the group received saline + PTZ and \# indicates significant difference $(p<0.05)$ from the group received gabapentin + PTZ, as analyzed by one-way ANOVA

\section{DISCUSSION}

The synthesized Schiff bases G1, G2, G3 and G4 were subjected to solubility and melting point determination. The structures of all the compounds were established on the basis of FTIR, ${ }^{1}$ HNMR and ${ }^{13}$ CNMR spectral data.

Antibacterial activity of gabapentin, its derived compounds and a standard drug (doxycycline) was studied at three doses by the agar well method, and zones of growth inhibition were measured for the assessment of antibacterial activity of the tested compounds. The parent drug, gabapentin, did not show inhibition of bacterial growth. All the synthesized compounds were found to be active against gram positive and gram-negative bacterial strains.

Table 4: Effects of different compounds upon mortality in mice following PTZ-evoked convulsions

\begin{tabular}{lccc}
\hline Group/Treatment & Dose & No. of animals with convulsion death & Mortality (\%) \\
\hline Saline & $0.25 \mathrm{ml} / \mathrm{kg}$ & $6 / 6$ & 100 \\
$\mathrm{G} 1$ & $10 \mathrm{mg} / \mathrm{kg}$ & $5 / 6$ & 83 \\
& $35 \mathrm{mg} / \mathrm{kg}$ & $4 / 6$ & 66 \\
& $75 \mathrm{mg} / \mathrm{kg}$ & $1 / 6$ & 16 \\
$\mathrm{G} 2$ & $10 \mathrm{mg} / \mathrm{kg}$ & $5 / 6$ & 83 \\
& $35 \mathrm{mg} / \mathrm{kg}$ & $4 / 6$ & 66 \\
& $75 \mathrm{mg} / \mathrm{kg}$ & $1 / 6$ & 16 \\
$\mathrm{G} 3$ & $10 \mathrm{mg} / \mathrm{kg}$ & $5 / 6$ & 83 \\
& $35 \mathrm{mg} / \mathrm{kg}$ & $3 / 6$ & 50 \\
& $75 \mathrm{mg} / \mathrm{kg}$ & $2 / 6$ & 33 \\
$\mathrm{G} 4$ & $10 \mathrm{mg} / \mathrm{kg}$ & $5 / 6$ & 83 \\
& $35 \mathrm{mg} / \mathrm{kg}$ & $3 / 6$ & 50 \\
& $75 \mathrm{mg} / \mathrm{kg}$ & $1 / 6$ & 16 \\
\hline
\end{tabular}


Table 5: Anticonvulsant activity of different drugs and synthesized compounds in PTZ-evoked chemical kindling model of epileptogenesis in mice

\begin{tabular}{llc}
\hline Group & Treatment (dose) & Seizure score \\
\hline Normal control & Normal Saline $(0.25 \mathrm{ml} / \mathrm{kg})$ & 0 \\
Positive control & Saline $(0.25 \mathrm{ml} / \mathrm{kg})+$ PTZ $(50 \mathrm{mg} / \mathrm{kg})$ & $4.5 \pm 0.06$ \\
Standard control -1 & Diazepam $(7.5 \mathrm{mg} / \mathrm{kg})+$ PTZ $(50 \mathrm{mg} / \mathrm{kg})$ & $0.1 \pm 0.05^{\star}$ \\
Standard control -2 & Gabapentin $(75 \mathrm{mg} / \mathrm{kg})+$ PTZ $(50 \mathrm{mg} / \mathrm{kg})$ & $0.8 \pm 0.06^{*}$ \\
G1 & G1 $(75 \mathrm{mg} / \mathrm{kg})+$ PTZ $(50 \mathrm{mg} / \mathrm{kg})$ & $0.7 \pm 0.06^{*}$ \\
G2 & G2 $(75 \mathrm{mg} / \mathrm{kg})+$ PTZ $(50 \mathrm{mg} / \mathrm{kg})$ & $0.9 \pm 0.07^{*}$ \\
G3 & G3 $(75 \mathrm{mg} / \mathrm{kg})+$ PTZ $(50 \mathrm{mg} / \mathrm{kg})$ & $2.7 \pm 0.13^{\text {\#\# }}$ \\
G4 & G4 $(7.5 \mathrm{mg} / \mathrm{kg})+$ PTZ $(50 \mathrm{mg} / \mathrm{kg})$ & $3.3 \pm 0.10^{\text {\#\# }}$ \\
\hline
\end{tabular}

Values are mean \pm SEM of eight observations. indicates significant $(p<0.05)$ difference from the positive control group and ${ }^{\#}$ indicates significant difference $(p<0.05)$ from the standard control 2 group, as analyzed by one-way ANOVA

Compound G1 showed greater activity against Micrococcus luteus, while it was found to possess comparable activity with doxycycline against the Stenotrophomonas maltophilia, Bacillus subtilis, Bacillus megaterium, Staphylococcus aureus, Serratia marcescens and Escherichia coli.

Compound G2 exhibited greater activity against Micrococcus luteus and Serratia marcescens when compared to the standard drug. Compound G4 showed larger zones of inhibition against Stenotrophomonas maltophilia when compared to the standard drug. Also, compound G3 exhibited larger inhibitory zones against Stenotrophomonas maltophilia and Serratia marcescens when compared to doxycycline. The mechanism of antibacterial activity of the Schiff base derivatives may involve hydrogen bonding between azomethine group of Schiff bases and various cellular molecules, resulting in an impairment of normal cellular functions $[6,7]$. Previous studies suggest that Schiff bases have well established biocidal activities [22], so the synthesized Schiff bases may be used for further studies of neurological diseases associated with bacterial infections.

$\mathrm{DPPH}$ is a stable radical, which is conveniently used for estimating antioxidant activity of chemicals. Compounds G1 and G2 showed significantly greater DPPH radical scavenging activity ( $82 \%$ and $92 \%$, respectively) compared to gabapentin (63\%). The enhanced antioxidant activity of $\mathrm{G} 1$ and $\mathrm{G} 2$ may be attributed to presence of phenolic hydroxyl and methoxy groups in the molecule [23]. Previous studies suggest that enhanced oxidative stress in brain tissue was involved in the induction of seizures, and PTZ induced seizures are associated with enhanced generation of free radicals in cerebral tissue of animals [24].

In addition, antioxidants are important in attenuating PTZ evoked seizures [25]. Therefore, we selected PTZ induced seizures in mice to study anticonvulsant activity of the synthesized compounds. All the compounds significantly decreased PTZ evoked seizures in mice compared to the saline treated control. Compounds $\mathrm{G} 1$ and $\mathrm{G} 2$ retained the potent anticonvulsant activity of gabapentin. However, the anticonvulsant activities of G3 and G4 were significantly less compared to gabapentin in the tested model. The proposed pharmacophore model suggests that lipophilic domain, hydrogen donor acceptor site and electron donor system are important for anticonvulsant activity of a molecule [4]. The parent drug and all the synthesized compounds contain these structural elements in their molecules.

However, compounds G3 and G4 have aromatic side chains at azomethine group, which might affect the electron donating activity, resulting decrease in anticonvulsant activity of these compounds as compared to gabapentin. Despite substitution at azomethine group, the compounds G1 and G2 retained anticonvulsant activity of gabapentin, which may be attributed to presence of additional hydroxyl groups, possibly eliminating the free radicals, which are main cause of neurodegenerative pathologies and seizures. Further studies on safety and other models of epilepsy are recommended. The present study may guide toward future development of anti-bacterial and neuromodulating drugs with additional antioxidant activity.

\section{CONCLUSION}

The newly synthesized gabapentin derivatives possess appreciable antibacterial and antioxidant activities relative to doxycycline and ascorbic acid, respectively. The anticonvulsant activity of G1 and G2 is comparable to that of the parent drug, gabapentin. Further investigations are recommended to interpret their mechanisms of actions and to demonstrate safety and efficacy in other experimental models. 


\section{DECLARATIONS}

\section{Conflict of interest}

No conflict of interest is associated with this work.

\section{Contribution of authors}

We declare that this work was done by the authors named in this article and all liabilities pertaining to claims relating to the content of this article will be borne by the authors. The authors of this paper declare that this work was done by them and all liabilities pertaining to claims relating to the content of this article will be borne by them. MF Saleem, MA Khan and I Ahmad conceptualized the study and contributed in manuscript writing. MF Saleem carried out experimental work, collected data and interpreted the results under the supervision of MA Khan and I Ahmad. $\mathrm{N}$ Aslam and $U$ Khurshid contributed in results analysis and manuscript writing. All authors read and approved the manuscript.

\section{Open Access}

This is an Open Access article that uses a funding model which does not charge readers or their institutions for access and distributed under the terms of the Creative Commons Attribution License (http://creativecommons.org/licenses/by/ 4.0) and the Budapest Open Access Initiative (http://www.budapestopenaccessinitiative.org/rea d), which permit unrestricted use, distribution, and reproduction in any medium, provided the original work is properly credited.

\section{REFERENCES}

1. Rudrapal $M$, De B. Chemistry and biological importance of heterocyclic Schiff's bases. Int Res J Pure Appl Chem 2013; 3(3): 232-249.

2. Murtaza G, Mumtaz A, Khan FA, Ahmad S, Azhar S, Najam-UI-Haq M, Atif M, Khan SA, Maalik A, Alam F, Hussain, I. Recent pharmacological advancements in schiff bases: A review. Acta Pol Pharm 2014; 71: 531 535.

3. Vigato PA, Tamburini $S$. The challenge of cyclic and acyclic Schiff bases and related derivatives. Coord Chem Rev 2004; 248(17-20): 1717-2128.

4. Mallesha L, Mohana KN, Veeresh B. Synthesis and biological activities of Schiff bases of gabapentin with different aldehydes and ketones: a structure-activity relationship study. Med Chem Res 2012; 21(1): 1-9.

5. Saremi K, Rad SK, Tayeby F, Abdulla MA, Karimian H, Majid NA. Gastroprotective activity of a novel Schiff base derived dibromo substituted compound against ethanol-induced acute gastric lesions in rats. BMC Pharmacol Toxicol 2019: 20(1): 13.

6. Chaturvedi D, Kamboj M. Role of Schiff base in drug discovery research. Chem Sci J 2016; 7(2): e114.

7. da Silva CM, da Silva DL, Modolo LV, Alves RB, de Resende MA, Martins CV, de Fatima A. Schiff bases: a short review of their antimicrobial activities. J Adv Res 2011; 2(1): 1-8.

8. Vibhute $A Y$, Zangade $S B$, Gurav VM, Vibhute $Y B$. Synthesis of series of 2-methyl-4-(substituted phenyl). $J$ Chem Pharm Res 2011; 3(5): 438-442.

9. Qion $Y, L v P C$, Shi $L$, Fang $R$, Song ZC, Zhu $H L$. Synthesis, antimicrobial activity of lamotrigine and its ammonium derivatives. J Chem Sci 2009; 121(4): 463470.

10. Figueroa-Valverde L, Diaz-Cedillo $F$, Lopez-Ramos $M$, Garcia-Cervera E, Torres-Cruz R, Reyna-Moo J. Antimicrobial activity of pregnenolone-carbamazepine complex on S. aureus, K. pneumoniae and E. coli. Int J Pharm Sci Rev Res 2010; 1: 7-12.

11. Sulukdjian $A$, L'homme $R$, Chanlon $A$, Moreau $N$. Gabapentenoid prescription in oral medicine and oral surgery practice. J Oral Med Oral Surg 2020; 26: 13.

12. Shokohi-Pour Z, Chiniforoshan H, Momtazi-Borojeni AA, Notash B. A novel Schiff base derived from the gabapentin drug and copper (II) complex: Synthesis, characterization, interaction with DNA/protein and cytotoxic activity. J Photochem Photobiol B: Biol 2016;162: 34-44.

13. Shin EJ, Jeong $J H$, Chung $Y H$, Kim WK, Ko KH, Bach JH, Hong JS, Yoneda Y, Kim HC. Role of oxidative stress in epileptic seizures. Neurochem Int 2011; 59(2): 122-137.

14. Grant SS, Hung DT. Persistent bacterial infections, antibiotic tolerance, and the oxidative stress response. Virulence 2013; 4(4): 273-283.

15. National Research Council, Guide for the care and use of laboratory animals, 8th edition. Washington: National Academics Press; 2011.

16. Bhat MA, Al-Omar MA. Synthesis, characterization and in vivo anticonvulsant and neurotoxicity screening of Schiff base of phthalimide. Acta Poloniae pharmaceutica-Drug Res 2011; 68(3): 375-380.

17. Khan MR., Khan MA, Ahmad K, Hamad A, Sajid-urRehman M, Asif HM, Younas M, Kamal, Y. Synthesis, characterization and in vitro antibacterial derivatives of doxycycline. RADS J Pharm Pharm Sci 2019; 7(4): 215226.

18. Negm NA, Zaki MF. Structural and biological behaviors of some nonionic Schiff-base amphiphiles and their $\mathrm{Cu}$ (II) and $\mathrm{Fe}$ (III) metal complexes. Colloids Surf $B$ Biointerfaces 2008; 64(2): 179-183.

19. Shahwar D, Ullah S, Ahmad M, Ullah S, Ahmad N, Khan MA. Hypoglycemic activity of Ruellia tuberose Linn (Acanthaceae) in normal and alloxon- induced diabetic rabbits. Iranian J Pharma Sci 2011; 7(2): 107-115.

Trop J Pharm Res, January 2021; 20(1): 152 
20. De Sarro G, Palma E, Costa N, Marra R, Gratteri S, DeSarro A, Rotiroti $D$. Effects of compounds acting on $G A B A(B)$ receptors in the pentylenetetrazole kindling model of epilepsy in mice. Neuropharmacol 2000; 39(11): 2147-2161.

21. Tai DN, Thanh N, Nam PD, Duc HT. $1 H$ and $13 C$ NMR spectra of some azomethines of 5-amino-2-phenylindole series. Chem J 2007; 45: 642-647.

22. Iqbal A, Siddiqui HL, Ashraf CM, Ahmed M, Weaver GW. Synthesis, characterization and antibacterial activity of azomethine derivatives derived from 2formylphenoxyacetic acis. Molecules 2007; 12(2): 245254.
23. Chen J, Yang J, Ma L, Li J, Shahzad N, Kim CK. Structure-antioxidant activity relationship of methoxy, phenolic hydroxyl, and carboxylic acid groups of phenolic acids. Sci Rep 2020; 10(1): 1-9.

24. Bashkatova V, Narkevich V, Vitskova G, Vanin A. The influence of anticonvulsant and antioxidant drugs on nitric oxide level and lipid peroxidation in the rat brain during penthylenetetrazole-induced epileptiform model seizures. Prog Neuro-Psychopharmacol Biol Psychiatry 2003; 27(3): 487-492.

25. Faghihi N, Mohammadi MT. Anticonvulsant and antioxidant effects of pitavastatin against pentylenetetrazol-induced kindling in mice. Adv Pharm Bul 2017; 7(2): 291-298. 